\title{
Sedum tarokoense (Crassulaceae), a new species from a limestone area in Taiwan
}

\author{
Chang-Tse Lu', Hung-Wen Lin ${ }^{1}$, Wei-Ting Liou ${ }^{1,2}$ and Jenn-Che Wang ${ }^{1 *}$
}

\begin{abstract}
Background: An unknown Sedum was found from the limestone region in Taiwan. After a detailed comparison with other congeners in Taiwan and neighboring countries, we identified this plant as a new species.

Results: This new taxon resembles S. nokoense Yamamoto, S. alfredii Hance, and S. uniflorum Hook. \& Arn. subsp. oryzifolium (Makino) H. Ohba, but differs in leaf shape, sepal morphology, and seed testa micro-morphology. Ecologically, this new taxon occurs exclusively on limestone, while S. nokoense and S. alfredii grow in non-limestone areas and S. uniflorum subsp. oryzifolium is only found on sandy seashores.

Conclusions: Sedum tarokoense H.W. Lin \& J.C. Wang is described as a new species. We provide a description, line drawing, and distribution map, as well as photograph, a key and a table to distinguish $\mathrm{S}$. tarokoense from its related species.
\end{abstract}

Keywords: Crassulaceae; Ecological isolation; Sedum; Sedum tarokoense; Seed testa; Taiwan

\section{Background}

Sedum L., the largest genus of Crassulaceae, consists of approximately 470 species of predominantly succulent plants. Sedum is cosmopolitan in distribution and mainly inhabits semiarid and mountainous regions.

According to the Flora of China, the genus can be divided into three sections (Fu and Ohba 2001). Section Sedum can be separated from sections Oeades and Filipes by adaxially gibbous carpels and follicles while sect. Oeades differs from sect. Filipes by having a spurred (vs. spurless) leaf base and petals that are mainly yellow (vs. white).

Phylogenetic studies of the Crassulaceae have grouped members of this family into 7 clades, whereas members of the traditionally defined Sedum were sorted into 4 separate clades, suggesting the polyphyly of the genus (van Ham and 't Hart 1998; Mort et al. 2001). Mayuzumi and Ohba (2004) further estimated the phylogenetic position of 74 taxa of Asian Sedoideae based on analyses of the cpDNA trnL-trnF region and rDNA ITS region. However, their results failed to establish a clear infrafamilial classification system.

\footnotetext{
* Correspondence: biofv017@ntnu.edu.tw

'Department of Life Science, National Taiwan Normal University, No. 88

Ting-Chow Rd, Sec. 4, Wenshan, Taipei 11677, Taiwan

Full list of author information is available at the end of the article
}

Tentatively following the classification of $\mathrm{Fu}$ and Ohba (2001), the Taiwanese species of Sedum, excluding $S$. drymarioides Hance and S. stellariifolium Franch., should be placed in sect. Sedum because the adaxially gibbous carpels and follicles. The characters usually used to distinguish taxa in sect. Sedum, such as leaf shape, leaf spur, and sepal base, are easily lost or become obscure in dried specimens, which might explain the inconsistency among earlier taxonomic treatments of Sedum in Taiwan. In two editions of the Flora of Taiwan, Liu and Chung (1977) and Tang and Huang $(1989,1993)$ both listed 14 species, but only 8 species are consistent between them, while the other 6 species are discrepant. For instance, S. formosana N.E. Brown was treated as $S$. alfredii Hance by Liu and Chung (1977), but recovered by Tang and Huang (1989, 1993); Liu and Chung (1977) treated S. microsepalum Hayata and S. parvisepalum Yamamoto as two distinct species, but Tang and Huang (1989, 1993) lumped them together; Liu and Chung (1977) described two new species, S. triangulosepalum and $S$. truncatistigma, but they were merged into $S$. microsepalum by Tang and Huang $(1989,1993)$. Therefore, an intensive systematic study to clarify the classification of Taiwanese Sedum is necessary. Recently, we revised Sedum in Taiwan and found a previously undescribed taxon. It has ever been collected by some 
taxonomists (see below) but was always identified as unknown species. We thoroughly surveyed the protologues and type specimens of all described species from Taiwan and compared it with related taxa in neighboring countries (China and Japan) around Taiwan. After detailed comparison of these species, we confirmed that this unknown plant is a new species and describe it here. Furthermore, in order to aid in identification, we also provide photograph, a key, and a table to compare this new species with closely related species.

\section{Methods}

Materials used in this study were collected from the field. Most plants were pressed and dried and the specimens are deposited in the TNU Herbarium. Voucher specimens for seed observations are also preserved at TNU.

Seeds for scanning electron microscopy (SEM) were collected from mature fruits. The air-dried seeds were directly coated with gold and examined with a Hitachi SM 2400 scanning electron microscope.

\section{Results}

Taxonomic treatment

Sedum tarokoense H.W. Lin \& J.C. Wang, sp. nov. TYPE: TAIWAN. Hualien County, Taroko National Park: Yenhai logging trail, H.W. Lin, S.D. Shen, C.C. Wang \& M.J. Lin 1003 (holotype: TNU; isotype: TNU, HAST) 太魯閣佛甲草 Figure 1 .

Sedum tarokoense is similar to S. uniflorum Hook. \& Arn. subsp. oryzifolium (Makino) Ohba, differing by having a woody stem base, orbicular to ellipsoid leaves, the sepal base obtuse to truncate, reddish green and ascending at anthesis, and petals oblonglanceolate to lanceolate with the base cuneate and follicles erect when fruiting. Sedum tarokoense also resembles S. nokoense Yamamoto and S. alfredii Hance, but differs from the latter them by smaller, orbicular to ellipsoid leaves and oblanceolate-spatulate sepals.

Herbs, perennial, fleshy. Stems thick, glabrous, usually reddish, with glandular spots, woody, $6-8(-10) \mathrm{cm}$ tall, basally decumbent, distally erect, rooting at nodes, base

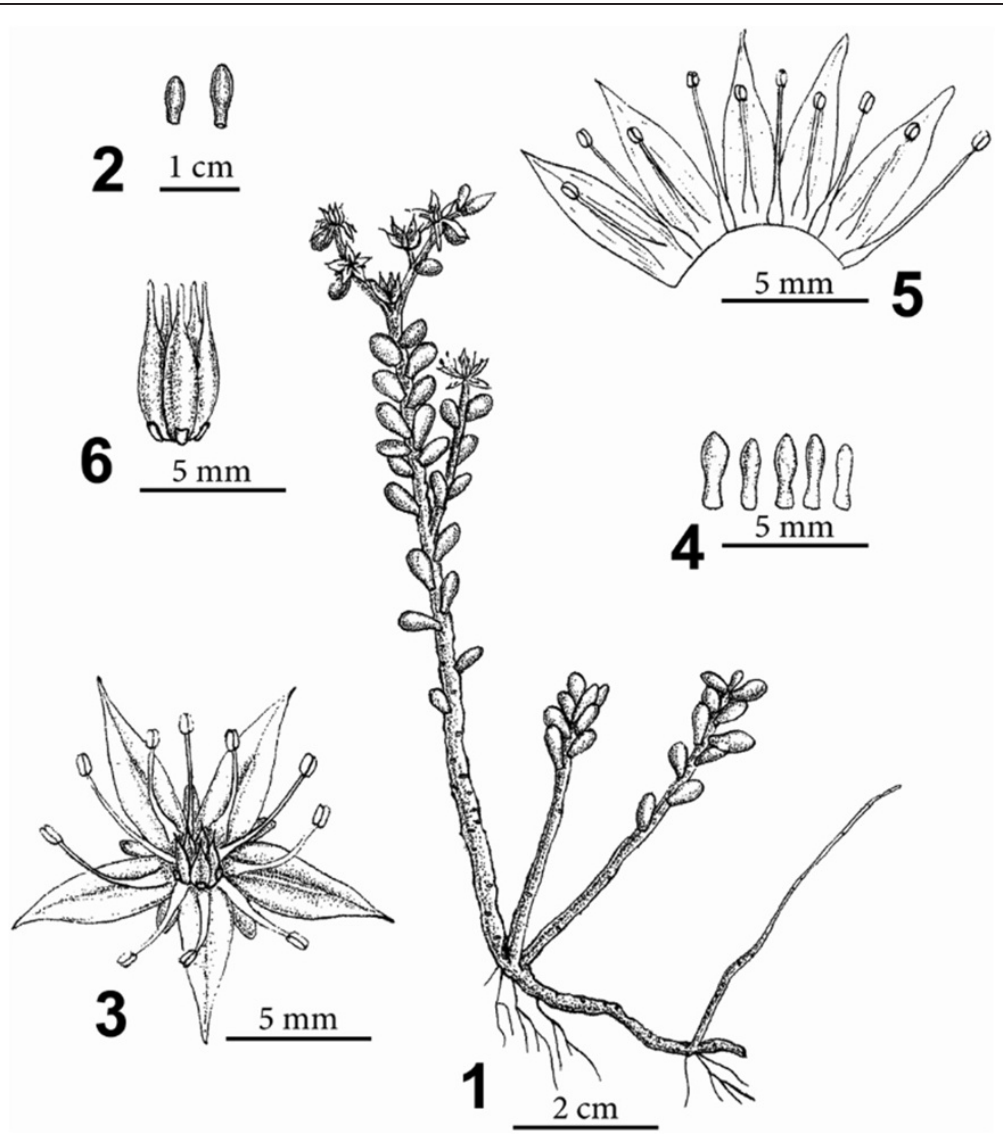

Figure 1 Sedum tarokoense H.W. Lin \& J.C. Wang. 1, Habit; 2, Leaves; 3, Flower; 4, Sepals; 5, Dissected corolla, showing attachment of stamens; $\mathbf{6}$, Carpels and nectar scales. (Drawn from the holotype). 
usually with young branches. Leaves alternate, usually reddish, approximate, densely arranged on upper part of stem, orbicular to ellipsoid, 5-6 $\mathrm{mm}$ long, 3-4 $\mathrm{mm}$ wide, 2-3 $\mathrm{mm}$ thick, margin entire, base truncate, spurred, apex obtuse, sometimes mucronate. Inflorescence spicate cyme, terminal, usually dichotomously branched or branch 1. Bracts leaf-like, round to elliptic, 3-4 $\mathrm{mm}$ long, about $3 \mathrm{~mm}$ wide. Flowers usually 3-5 per branch, lower flowers short pedunculate, upper flowers sessile. Sepals 5, free, equal to subequal in length, oblanceolate-spatulate, $2.5-3 \mathrm{~mm}$ long, 1-1.2 mm wide, base obtuse to truncate, slightly spurred, apex round or obtuse, reddish green, glabrous, ascending at anthesis, persistent until carpels mature. Petals 5, oblong-lanceolate to lanceolate, $4-5 \mathrm{~mm}$ long, $2 \mathrm{~mm}$ wide, base cuneate, apex acute to acuminate, yellow. Stamens 10, 2-whorled; outer stamens connate between petals, opposite sepals; inner petals connate in middle of petal. Anthers orangish yellow, suborbicular to elliptic, $0.5-0.7 \mathrm{~mm}$ long, $0.4 \mathrm{~mm}$ wide, base emarginate, apex slightly retuse. Filaments filiform, about 3-3.5 mm long. Glands 5, opposite carpels, less than $1 \mathrm{~mm}$ long, square, apex slightly emarginate. Carpels 5 , free, connate at base, oblong, c. $5 \mathrm{~mm}$ long, glabrous, apex rostrate, styles less than $1 \mathrm{~mm}$ long. Fruit a follicle. Seeds numerous, $0.7-0.94 \mathrm{~mm}$ long, oblong, dark yellow or brown when mature.

\section{Additional specimen examined}

TAIWAN. Hualien Hsien, Taroko National Park: Yenhai logging trail, elev. ca. $1200 \mathrm{~m}$, J. C. Wang 7656 (TNU); same loc., C. H. Chen 1193 (TNU, HAST); same loc.,
C. I Peng 12404, 13009 (HAST); same loc., elev. 300900 m, P.-F. Lu 9676 (TAIF); same loc., C.-T. Lu \& W.-T. Liou 2204, 2205 (TNU); Chuilu Ancient Trail, P. F. Lu 22034 (HAST).

\section{Seed micromorphology}

Seeds of Sedum are usually minute (ca. $0.5-1 \mathrm{~mm}$ long), ellipsoid to orbicular and appear similar to the naked eye. The ornamentation of the testa of seeds, however, is widely diversified and has been considered to be an important taxonomic character in infrageneric classification (Fröderström 1930, 1931, 1932, 1936; 't Hart and Berendsen 1980; Jin et al. 2008). 't Hart and Berendsen (1980) considered the size and shape of testa cells, presence or absence of papillae, the number of papillae per cell, size of the papillae, and whether the papillae are laterally fused and whether a reticulum is present as characteristics that are variable among taxa.

In this study, we observed the seeds of S. tarokoense, S. nokoense, and S. uniflorum subsp. oryzifolium by SEM and also referred to observations on S. alfredii by Jin et al. (2008) to compare the ornamentation of the testa among these closely related taxa. The seeds of all four taxa are similar in shape, all ellipsoid to globose, but slightly different in size. Sedum tarokoense has larger seeds, $0.70-0.94 \times 0.32-0.44 \mathrm{~mm}$, than the other three taxa (Figure 2, Table 1). The ornamentation of the testa in all four taxa are unipapillate (Figure 2), but the shape, size and surface ornamentation of the papillae are different. Sedum tarokoense has larger papillae (ca. 20-25 $\mu \mathrm{m}$ ) that cover nearly $90 \%$ of the outer surface of the testa cells, resulting in dense distribution of the papillae. The

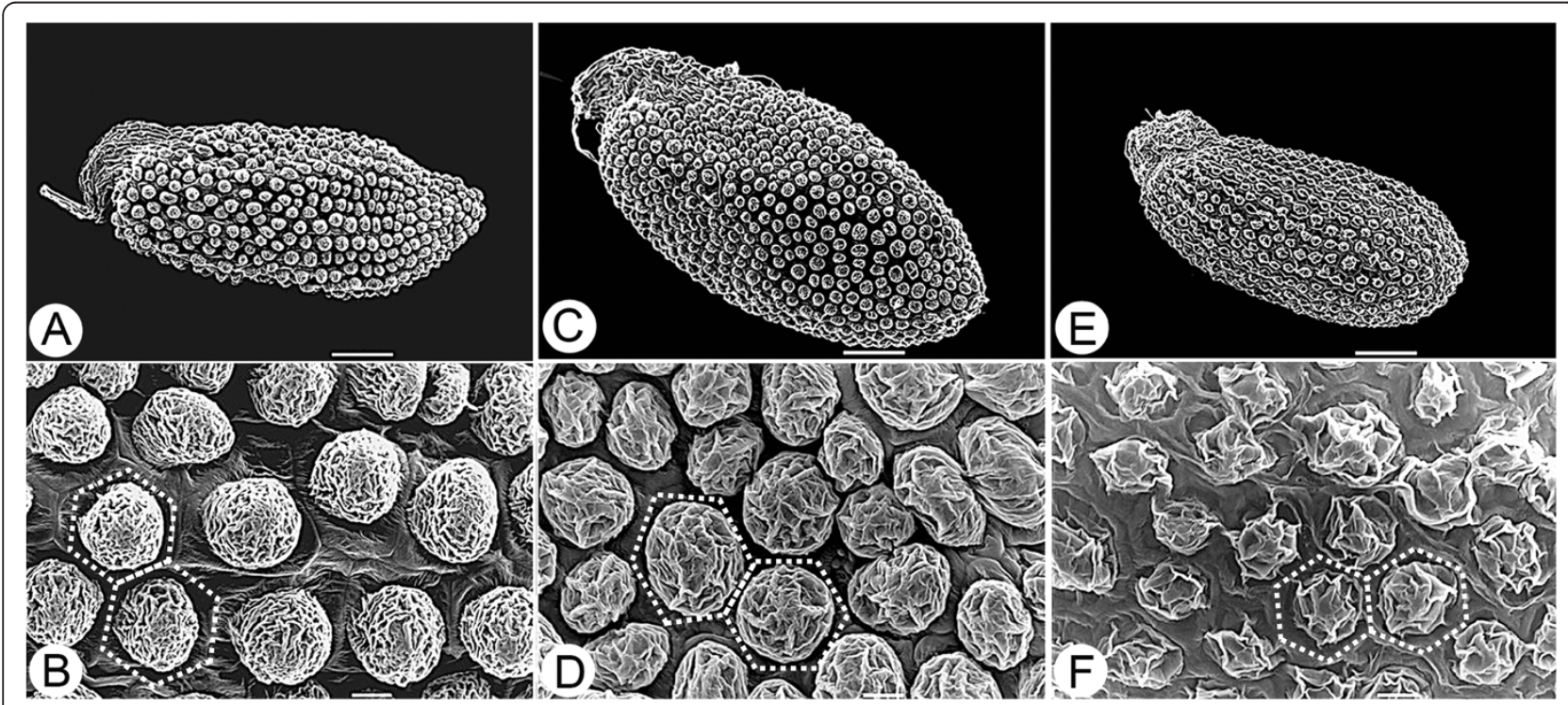

Figure 2 Seed micromorphology of S. tarokoense and two related species. A \& B, S. nokoense (from W. S. Tang 1827); C \& D, S. tarokoense (from H. W. Lin 1003); E \& F, S. uniflorum subsp. oryzifolium (from H. W. Lin 912). Dashed lines show cell boundaries. $\mathbf{A}, \mathbf{C} \& \mathbf{E}$, bar $=100 \mu$ m; B, D \& $\mathbf{F}$, bar $=10 \mu \mathrm{m}$. 
Table 1 Comparison of diagnostic characteristics of S. tarokoense and related taxa

\begin{tabular}{|c|c|c|c|c|}
\hline TAXA & S. alfredii & S. nokoense & S. tarokoense & S. uniflorum subsp. oryzifolium \\
\hline Stem & Green, thick & Reddish, thick & Reddish, thick & Reddish, slender \\
\hline Leaves & $\begin{array}{l}\text { Green, linear-cuneate, } \\
\text { spatulate or obovate, } 12-30 \times \\
2-6 \mathrm{~mm} \text {, apex obtuse }\end{array}$ & $\begin{array}{l}\text { Green; spatulate, } 8-10 \times \\
3-5 \mathrm{~mm} \text {, apex obtuse }\end{array}$ & $\begin{array}{l}\text { Reddish green; orbicular to } \\
\text { ellipsoid, rather thick, } 5-6 \times \\
3-4 \times 2-3 \mathrm{~mm} \text {, apex obtuse }\end{array}$ & $\begin{array}{l}\text { Yellowish green, densely } \\
\text { arranged, ovate-oblong to } \\
\text { oblong, } 4-7 \times 2 \mathrm{~mm} \text {, apex round }\end{array}$ \\
\hline Sepal & $\begin{array}{l}\text { Unequal in length, linear- } \\
\text { spatulate }\end{array}$ & $\begin{array}{l}\text { Unequal in length, } \\
\text { oblanceolate-spatulate to } \\
\text { linear-lanceolate }\end{array}$ & $\begin{array}{l}\text { Near equal to slightly unequal in } \\
\text { length, oblanceolate-spatulate }\end{array}$ & $\begin{array}{l}\text { Nearly equal in length, oblong- } \\
\text { linear }\end{array}$ \\
\hline Inflorescence & Corymbiform, many flowered & $\begin{array}{l}\text { Spicate-cyme, usually } \\
\text { dichotomously branched }\end{array}$ & $\begin{array}{l}\text { Spicate-cyme, usually } \\
\text { dichotomously branched or only } \\
\text { one branch, usually 3-5 flowers } \\
\text { in each branch }\end{array}$ & $\begin{array}{l}\text { Spicate-cyme, usually } \\
\text { dichotomously branched or only } \\
\text { one branch, usually 4-6 flowers } \\
\text { in each branch }\end{array}$ \\
\hline Petal & $\begin{array}{l}\text { Lanceolate to lanceolate- } \\
\text { oblong, } 4-6 \times 1.6-1.8 \mathrm{~mm} \text {, } \\
\text { apex mucronate }\end{array}$ & $\begin{array}{l}\text { Lanceolate, } 4-5 \times 1.5-2 \mathrm{~mm} \text {, } \\
\text { apex acuminate }\end{array}$ & $\begin{array}{l}\text { Oblong-lanceolate to lanceolate, } \\
4-5 \times 1-1.2 \mathrm{~mm} \text {, apex acute to } \\
\text { acuminate }\end{array}$ & $\begin{array}{l}\text { Obovate-spatulate, } 4 \times 1.5-2 \mathrm{~mm} \text {, } \\
\text { apex acute to acuminate }\end{array}$ \\
\hline Seed & $\begin{array}{l}\text { Reddish brown, } 0.732 \pm \\
0.010 \times 0.311 \pm 0.003 \mathrm{~mm} \text {; } \\
\text { papilla surface near glabrous } \\
\text { (Jin et al. 2008) }\end{array}$ & $\begin{array}{l}\text { Yellowish brown, } 0.6-0.75 \times \\
0.23-0.32 \mathrm{~mm} \text {; papilla ca. } \\
20 \mu \mathrm{m} \text {, surface obviously } \\
\text { irregularly folded }\end{array}$ & $\begin{array}{l}\text { Dark yellow to brown, } 0.7-0.94 \times \\
0.32-0.44 \mathrm{~mm} \text {; papilla ca. } \\
20-25 \mu \mathrm{m} \text {, surface obviously } \\
\text { irregularly folded }\end{array}$ & $\begin{array}{l}\text { Dark yellow to brown, } 0.5-0.6 \times \\
0.23-0.27 \mathrm{~mm} \text {; papilla ca. } 15 \mu \mathrm{m} \text {, } \\
\text { surface obviously irregularly } \\
\text { folded }\end{array}$ \\
\hline
\end{tabular}

other three taxa have papillae ca. $15-20 \mu \mathrm{m}$ in diameter, resulting in a looser distribution of papillae (Figure 2, Table 1). In addition, the papillae are round in $S$. tarokoense, S. alfredii, and S. nokoense, while they are irregular in S. uniflorum subsp. oryzifolium. Further, the surface ornamentation of the papillae is nearly smooth in $S$. alfredii but obviously irregularly folded in S. tarokoense and the other two taxa.

\section{Geographical distribution}

Sedum tarokoense is a narrowly distributed endemic species, currently found in only two localities in the Taroko area of Hualien Hsien, eastern Taiwan. The two localities are on opposite sides of Taroko Gorge (Figure 3).

\section{Ecology}

Sedum tarokoense occurs in exposed, sunny places on limestone scree slopes. Limestone areas are characterized by calcium-rich, high $\mathrm{pH}$ soils (Zhu 2003). Additionally, limestone outcrops are often steep and rocky, making them vulnerable to erosion, which results in shallow soils. Although calcium and organic matter are abundant in limestone soils, total mineral availability is generally low due to the shallow soils (Du et al. 2011). Changes in morphology and physiology that help plants

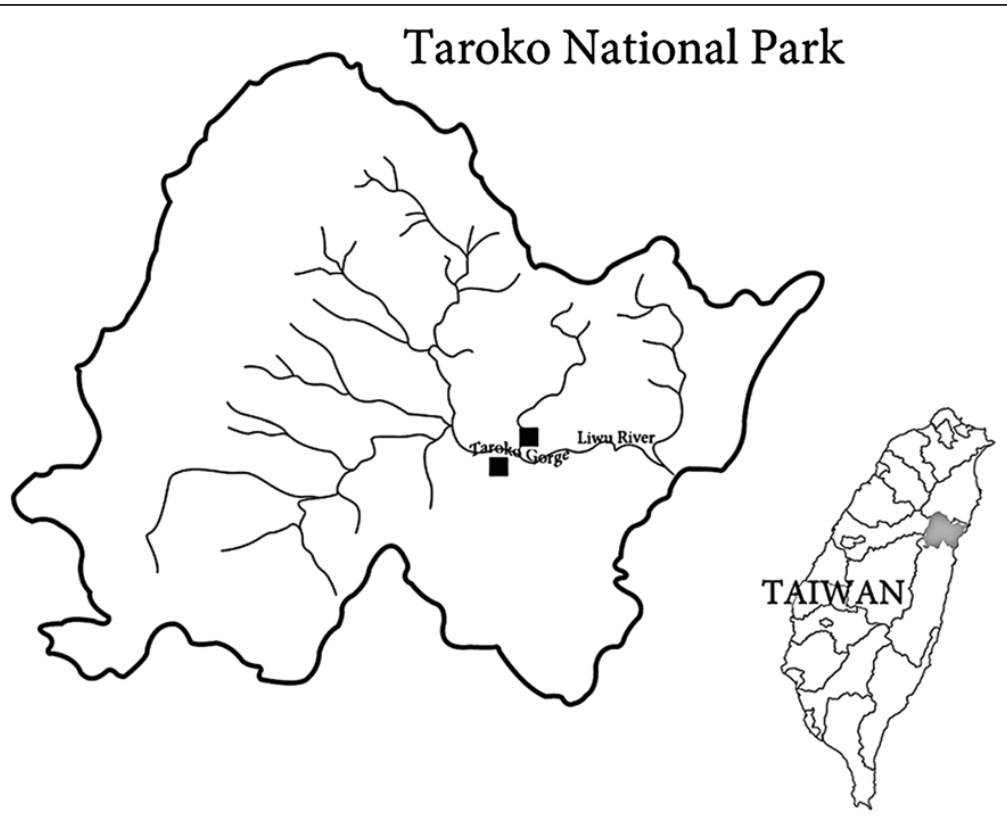

Figure 3 Geographical distribution of S. tarokoense (घ), showing localities on opposite sides of Taroko Gorge. 
adapt to limestone environments include small, thick leaves, well developed palisade tissue, thick cuticles, and sunken stomata (Rong et al. 2005). These changes could have led limestone-adapted plants to gradually diverge from closely related species.

Adaptation to different soil types is evidence of strong natural selection imposed by ecological discontinuities (Wallace 1858). Some modern works on serpentine plants provided good examples of this edaphic specialization (reviewed in Brady et al. 2005). Due to the different chemical components between serpentine and nonserpentine soils, plant populations could produce habitat isolation (Kay et al. 2011). To adapt to serpentine soils, plant species often possess morphologies somewhat distinct from closely related species not adapted to serpentine sites. Subsequently genetic differentiation between these populations will cause them to produce reproductive isolation and even results in ecological speciation (Schluter 2001; Yost et al. 2012). Therefore, this divergent adaptation can affect the components of reproductive isolation and contribute to the generation and maintenance of closely related species (Yost et al. 2012).

Like the cases of serpentine plants, limestone plants also suffer strong natural selection which accounts for the high level of endemism in the Taroko regions. The endemic plants include Euphorbia tarokoensis Hayata, Gentiana tarokoensis C.H. Chen \& J.C. Wang, Senecio tarokoensis C.-I Peng, Spiraea tarokoensis Hayata and Galium tarokoense Hayata. Compared with the related species S. nokoense and S. alfredii, S. tarokoense occurs exclusively on limestone and has smaller and thicker leaves, and would be expected to have some physiological changes. We speculate that $S$. tarokoense may be the result of ecological isolation. Further study should be carried out to examine this hypothesis. On the other hand, the discovery of this new limestone plant also suggests that isolated limestone areas in Taiwan are relatively underexplored and understudied and are a priority for taxonomic work (Peng et al. 2012).

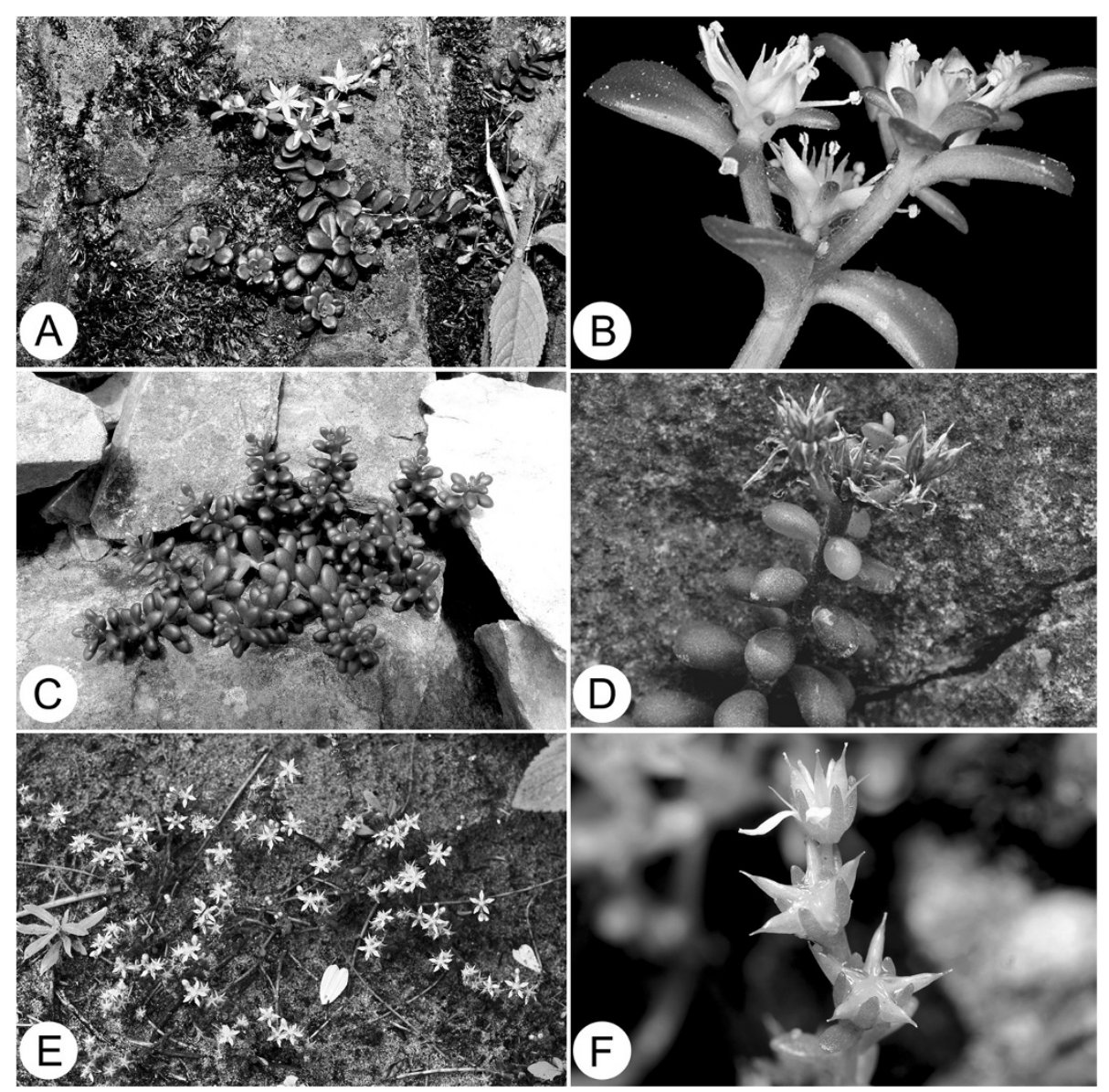

Figure 4 Sedum tarokoense H.W. Lin \& J.C. Wang and its related species. A \& B, S. nokoense; A, Habit; B, Flowering branch, showing free sepals; C \& D, S. tarokoense; C, Habit; D, Fruiting branch, showing fruit erect when mature; E \& F, S. uniflorum subsp. oryzifolium; E, Habit; $\mathbf{F}$, Fruiting branch, showing sepals erect and fruit spread when mature. 


\section{Conservation status}

Only two locations, each with approximately 500 adult individuals of $S$. tarokoense, were counted in an area of $10 \mathrm{~km}^{2}$. Both populations are in Taroko National Park, so they are under no immediate threat of extinction. According to the IUCN red list categories criteria (IUCN 2001), S. tarokoense is categorized as Vulnerable (VU D1+2).

\section{Phenology}

Flowering May to June; fruiting June to July.

\section{Etymology}

The specific epithet is derived from the collection locality of the holotype: Taroko, Hualien.

\section{Discussion}

Sedum tarokoense is most similar to S. uniflorum Hook. \& Arn. subsp. oryzifolium (Makino) Ohba of Japan and northern Taiwan, but can be distinguished from the latter by woody stem base and many other morphological feature (Table 1, Figure 4). Sedum tarokoense also resembles S. nokoense Yamamoto of Taiwan and S. alfredii Hance of Mainland China in gross morphology and seed micromorphology (Figure 2). Herein we provide photograph (Figure 4), a detailed comparison (Table 1) and a key to $S$. tarokoense and these three related species in aid of their identification.

\section{Key to Sedum tarokoense and related species}

1. Leaves linear-cuneate, spatulate or obovate, 8-30 $\times 2-6 \mathrm{~mm}$, base attenuate.

2. Leaves spatulate, $8-10 \times 3-5 \mathrm{~mm}$; inflorescences spicate cyme, usually dichotomously branched; petals acuminate. S. nokoense.

2. Leaves linear-cuneate, spatulate or obovate, 12-30 × 2-6 mm; inflorescences corymbiform; petal apex mucronate. S. alfredii.

1. Leaves ovate-oblong to oblong or orbicular to ellipsoid, $4-7 \times 2-4 \mathrm{~mm}$, base truncate.

3. Stems $0.5-1 \mathrm{~mm}$ in diam., base herbaceous; leaves ovate-oblong to oblong, $4-7 \times 2 \mathrm{~mm}$; sepals erect at anthesis; petals obovatespatulate. S. uniflorum subsp. oryzifolium.

3. Stems $1.8-2.4 \mathrm{~mm}$ in diam., base woody; leaves orbicular to ellipsoid, 5-6 $\times 3-4 \mathrm{~mm}$; sepals ascending at anthesis; petals oblong-lanceolate to lanceolate. $S$. tarokoense.

\section{Conclusions}

Sedum tarokoense H.W. Lin \& J.C. Wang is described as a new species and illustrated based on the morphological, seed micromorphology and ecological differentiation. The present study shows seed testa is a good character to aid in distinguishing the similar species. Moreover, the soil substrate should be an important factor to cause ecological isolation of Sedum species.

\section{Competing interests}

The authors declare that they have no competing interests.

\section{Authors' contributions}

HWL, WTL \& CTL collected the materials and carried out the morphological comparison. HWL performs the SEM observation of seeds. CTL, JCW drafted the manuscript. All authors read and approved the final manuscript.

\section{Acknowledgments}

We would like to extend our thanks to Dr. David E. Boufford and an anonymous reviewer for improving the manuscript and providing critical comments. We also thank Mr. Chuang, Kuei-Chun for kindly helping to prepare the distribution map. This study was supported by a grant (NSC89-2321-B-003-002) from the National Science Council, ROC.

\section{Author details}

${ }^{1}$ Department of Life Science, National Taiwan Normal University, No. 88, Ting-Chow Rd, Sec. 4, Wenshan, Taipei 11677, Taiwan. ${ }^{2}$ The Experimental Forest, College of Bio-Resources and Agriculture, National Taiwan University, No. 12, Sec. 1, Chien-Shan Rd, Chushan, Nantou 55750, Taiwan.

Received: 30 October 2013 Accepted: 30 October 2013

Published: 18 November 2013

\section{References}

't Hart H, Berendsen W (1980) Ornamentation of the testa in Sedum (Crassulaceae). Plant Syst Evol 135:107-117

Brady KU, Kruckeberg AR, Bradshaw HD, Jr (2005) Evolutionary ecology of plant adaptation to serpentine soils. Annu Rev Ecol Evol Syst 36:243-266

Du YX, Pan GX, Li LQ, Hu ZL, Wang XZ (2011) Leaf N/P ratio and nutrient reuse between dominant species and stands: predicting phosphorus deficiencies in karst ecosystems, Southwestern China. Environ Earth Sci 64:299-309

Fröderström H (1930) The genus Sedum L. A systematic essay. Part 1. Acta Horti Gothob 5(append):3-75

Fröderström H (1931) The genus Sedum L. A systematic essay. Part 2. Acta Horti Gothob 6(append):3-111

Fröderström H (1932) The genus Sedum L. A systematic essay. Part 3. Acta Horti Gothob 7(append): $1-126$

Fröderström H (1936) The genus Sedum L. A systematic essay. Part 4. Acta Horti Gothob 10(append):1-262

Fu K, Ohba H (2001) Crassulaceae. In: Wu ZY, Raven PH (ed) Flora of China, vol. 8. Science Press, Beijing and Missouri Botanical Garden, St. Louis, pp 202-268

IUCN (2001) IUCN red list categories and criteria, ver. 3.1. Gland, Switzerland and Cambridge, UK

Jin XF, Li Q, Lu YH, Zhang HW, Wang HZ (2008) Seed micromorphology of Sedum (s. I.) from Zhejiang and its taxonomic implications. J Zhejiang Univ (Agric \& Life Sci) 34:409-417

Kay KM, Ward KL, Watt LR, Schemske DW (2011) Plant speciation. In: Harrison SP Rajakaruna N (ed) Serpentine: evolution and ecology in a model system. University of California Press, Berkeley, California, USA, pp 71-96

Liu TS, Chung NJ (1977) Crassulaceae. In: Li HL et al. (ed) Flora of Taiwan, vol. 3. Epoch. Pub, Taipei, pp 10-24

Mayuzumi S, Ohba H (2004) The phylogenetic position of Eastern Asian Sedoideae (Crassulaceae) inferred from chloroplast and nuclear DNA sequences. Syst Bot 29:587-598

Mort ME, Soltis DE, Soltis PS, Francisco-Ortega J, Santos-Guerra A (2001) Phylogenetic relationships and evolution of Crassulaceae inferred from matK sequence data. Am J Bot 88:76-91

Peng C-I, Kono Y, Chen CJ, Hsu TC, Chung SW (2012) Pouzolzia taiwaniana (Urticaceae), a new species from Taiwan. Bot Stud 53:387-392

Rong L, Wang SJ, Liu N, Yang L (2005) Leaf anatomical characters and its ecological adaptation of the pioneer species in the karst mountain area- 
with a special reference to the Huajiang Canyon of Guizhou. J Mount Sci 23:35-42

Schluter D (2001) Ecology and the origin of species. Trends Ecol Evol 16:372-380 Tang WS, Huang TC (1989) Notes on the Flora of Taiwan (6) - The Sedoideae (Crassulaceae). Taiwania 34:157-179

Tang WS, Huang TC (1993) Crassulaceae. In: Huang TC et al. (ed) Flora of Taiwan, vol. 3, 2nd edition. Editorial Committee, Dept. Bot., NTU, Taipei, Taiwan, pp 15-34

van Ham RCHJ, 't Hart H (1998) Phylogenetic relationships in the Crassulaceae inferred from chloroplast DNA restriction-site variation. Am J Bot 85:123-134

Wallace AR (1858) On the tendency of varieties to depart indefinitely from the original type. J Proc Linn Soc Zool 3:53-62

Yost JM, Barry T, Kay KM, Rajakaruna N (2012) Edaphic adaptation maintains the coexistence of two cryptic species on serpentine soils. Am J Bot 99:890-897

Zhu SQ (2003) Ecological Research on Karst Forest (III). Guizhou Science and Technology Press, Guiyang

doi:10.1186/1999-3110-54-57

Cite this article as: Lu et al: Sedum tarokoense (Crassulaceae), a new species from a limestone area in Taiwan. Botanical Studies 2013 54:57.

\section{Submit your manuscript to a SpringerOpen ${ }^{\circ}$} journal and benefit from:

- Convenient online submission

- Rigorous peer review

- Immediate publication on acceptance

- Open access: articles freely available online

- High visibility within the field

- Retaining the copyright to your article

Submit your next manuscript at $>$ springeropen.com 